\title{
Acil Servise Diyabetik Ketoasidoz Tablosu ile Başvuran Hastaların Yeni Tanı Diyabet Açısından Değerlendirilmesi
}

\section{Evaluation of New-Onset Diabetes in Patients Presenting Emergency Service with a Diabetic Ketoacidosis Attack} \author{
Mehmet Karakum**** \\ Derince Eğitim ve Araştırma Hastanesi, Acil Servis, Kocaeli, Türkiye, \\ *Bakırköy Sadi Konuk Eğitim ve Araştırma Hastanesi, Acil Tıp Kliniği, İstanbul, Türkiye, \\ **Haydarpaşa Numune Eğitim ve Araştırma Hastanesi, Acil Tıp Kliniği, İstanbul, Türkiye, \\ ***Dr.Lütfi Kırdar Kartal Eğitim ve Araştırma Hastanesi, Acil Tıp Kliniği, Istanbul, Türkiye, \\ ****Şanlıurfa Eğitim ve Araştırma Hastanesi, Acil Servis, Şanlıurfa, Türkiye
}

Yavuz Yiğit, Doğaç Niyazi Özüçelik* , Harun Ayhan**, Emin Gökhan Gencer***,

\section{Özet}

Amaç: Bu araştırmanın amacl, acil serviste diyabetik ketoasidoz (DKA) tablosu ile başvuran hastalarda yeni tanı diyabet (DM) oranını araştırmaktır.

Yöntem: Araştırmaya 01 Nisan 2009-01 Nisan 2011 tarihleri arasında İstanbul Göztepe Eğitim ve Araştırma Hastanesi erişkin acil servisine başvuran ve diyabetik ketoasidoz tanısı konulan hastalar içinde dosya bilgileri tam olan 57 hasta alındı. Hastaların klinik ve laboratuvar verileri hasta dosyalarından geriye dönük olarak incelendi.

Bulgular: Araştırmaya alınan hastalardan, \%45.6'sında tip 1, \%33.3'ünde tip 2, \%21'inde ise yeni tanı diyabet sap-tandı. DKA tanısı alan hastaların başvuru arter kan gazı pH, $\mathrm{HCO}$ değerleri, serum sodyum ve potasyum, başvuru zamanı, plazma glukoz değeri açısından tip 1, tip 2 ve yeni tanı DM hastaları arasında istatistiksel olarak anlamlı fark görülmezken ( $p>0.05), \mathrm{HbA} 1 \mathrm{c}$ değerleri yeni tanı DM hastalarında istatistiksel olarak anlamlı derecede yüksekti.

Sonuç: Diyabetik ketoasidoz tanısı konulan farklı tiplerdeki hastalarda diyabet tipleri açısından etiyolojik nedenler, yaş ve $\mathrm{HbA} 1 \mathrm{c}$ değerleri dışında istatistiksel açıdan anlamlı bir veriye rastlanmadı. Acil servise başka nedenlerle baş-vuran hastalarda kan şekeri yüksekliğinin tespit edilmesi nadir değildir. Bu tip hastalarda altta yatan diabetes mellitus açısından dikkatli olunması olası diyabetik ketoasidoz ataklarının engellenmesi bakımından önemlidir. (Haseki Tıp Bülteni 2013; 51: 168-72)

Anahtar Kelimeler: Diabetes mellitus, acil servis
Abstract

Aim: The aim of this study was to investigate the rate of new-onset diabetes mellitus (DM) in patients presenting to our emergency department with diabetic ketoacidosis.

Methods: We retrospectively evaluated hospital records of patients who presented to the Emergency Department at Istanbul Goztepe Research and Training Hospital between 01 April 2009 and 01 April 2011 and were diagnosed with diabetic ketoacidosis. 57 patients having complete clinical data were included in the study.

Results: $45.6 \%$ of patients had type 1 DM, 33.3\%- type 2 DM, and $21 \%$ of them were with new-onset DM. No statistically significant difference was found between type 1 DM, type 2 DM and new-onset DM patients with respect to arterial blood $\mathrm{pH}$ and $\mathrm{HCO} 3$ levels and serum sodium, potassium and plasma glucose levels at presentation as well as time of presentation ( $p>0.05$ ), while $\mathrm{HbA} 1 \mathrm{c}$ levels showed statistically significant difference in new-onset DM patients.

Conclusion: No statistically significant difference was found between types of DM in patients diagnosed with diabetic ketoacidosis except for precipitating factors, age and $\mathrm{HbA} 1 \mathrm{c}$. Detecting high blood glucose levels in patients presenting to emergency room for reasons other than DM is not a rare condition. Cautious evaluation and recognition of these patients in emergency room for the possibility of undiagnosed DM is important for prevention of future diabetic ketoacidosis episodes. (The Medical Bulletin of Haseki 2013; 51: 168-72)

Key Words: Diabetes mellitus, emergency room
Yazışma Adresi/Address for Correspondence: Yavuz Yiğit Derince Eğitim ve Araştırma Hastanesi, Acil Servis, Kocaeli, Türkiye E-posta: dryavuzyigit@gmail.com

Geliş Tarihi/Received: 01 Mayıs 2013 Kabul Tarihi/Accepted: 29 Mayıs 2013
Haseki Tıp Bülteni, Galenos Yayınevi tarafından basıımıştır. The Medical Bulletin of Haseki Training and Research Hospital, published by Galenos Publishing. 


\section{Giriş}

Diabetes mellitus (DM), akut komplikasyonların önlenmesi ve uzun dönem komplikasyonların azaltılması için medikal bakım, destek ve kişisel hasta eğitimine gerek duyulan kronik bir hastalıktır.

Diyabetik ketoasidoz (DKA), diyabetin en ölümcül akut komplikasyonlarından birisidir. DKA, insidansının yıllık 4.68 epizot/1000 diyabet hastası olduğu tahmin edilmektedir. ABD'de yıllık 500.000 hastane yatışından sorumlu olduğu ve toplam maliyetinin ise, yaklaşık 2.4 milyar \$ olduğu tahmin edilmektedir (1).

DKA'nın üç başlıca biyokimyasal bulgusu hiperglisemi, ketoz ve asidoz, dolaşımdaki yetersiz insülin aktivitesi ve karşıt düzenleyici hormonların etkisi sonucu ortaya çıkmaktadır. Bu hormonal dengesizlik, dokulardan gelen maddelerin (kastan amino asitler, laktat ve pirüvat; yağ dokusundan serbest yağ asitleri, gliserol) karaciğerde aktif olarak glukoz ve keton cisimciklerine (beta hidroksi bütirat, asetoasetat, aseton) çevrilmelerine, sonra da dolaşıma gereğinden fazla dağılımına yol açar. Sonuç olarak hiperglisemi (>250 mg/dl) ve ketoasidoz ( $\mathrm{pH}<7.30)$, dehidratasyon ve elektrolit kaybına neden olan osmotik diüreze yol açar.

DKA tanı kriterleri; plazma glikozunun (>250 mg/dl), $\mathrm{pH}^{\prime}$ ının $<7.30$, serum $\mathrm{HCO}^{3 \prime}$ ının $<15 \mathrm{mEq} / \mathrm{l}$, idrar/serum keton oranının pozitif, anyon açığının >10 olmasıdır (2).

ilk olarak 1877 'de Claude Bernard'ın ortaya koyduğu stres hiperglisemisi de acil serviste sık rastlanan bir durumdur. Hastalıkların özellikle akut dönemlerinde ve travma sonrası hastalarda gelişen hiperglisemiyi ifade eden stres hiperglisemisi diyabetik olmayan ve diyabetik bir çok acil servis hastasında görülmektedir (3).

Bu araştırmadaki amacımız DKA tanısı konulan hastaların klinik ve laboratuvar bulgularının incelenerek DKA tablosu ile başvuran hastalarda yeni tanı diyabet sıklığını araştırmaktır.

\section{Yöntemler}

Bu araştırma 01.04.2009-01.04.2011 tarihleri arasında istanbul Göztepe Eğitim ve Araştırma Hastanesi Erişkin Acil Servisi'nde DKA tanısı konularak hastaneye yatırılan ve HbA1c istenen 57 hasta üzerinde yapılmıştır. On sekiz yaş altı, başka merkezde tanı konulmuş, hastanemizde tanı konulduktan sonra sevk edilmiş ve dosyaları eksik hastalar çalışma dışı bırakılmıştır.

Araştırmaya alınan hastaların dosyaları geriye dönük değerlendirilerek, yaş, cinsiyet, başvuru zamanı, kronik renal yetmezlik, kalp yetersizliği, hipertansiyon gibi eşlik eden hastalıklarının olup olmadığı, diyabete yönelik kullandıkları ilaçlar, ailede diyabet öyküsü olup olmadığı, DKA gelişimine sebep olan travma, enfeksiyon, tedavi uyumsuzluğu gibi tetikleyici nedenler kaydedilmiştir.
Araştırma için Göztepe Eğitim ve Araştırma Hastanesi etik kurulundan onay alınmıştır.

Hastaların başvuru anındaki kan glukoz, sodyum, potasyum, $\mathrm{pH}$ ve $\mathrm{HCO}^{3}$ değerleri ile tanı konulduktan sonra ölçülen $\mathrm{HbA} 1 \mathrm{c}$ değerleri kaydedilmiştir.

Araştırmaya dahil edilen hastalar tip 1, tip 2 ve yeni tanı diyabet şeklinde üç gruba ayrılmıştır. Bu üç grubun başvuru anındaki kan glukoz değeri, HbA1c, kan biyokimya değerleri ve demografik verileri karşılaştıılarak aralarında istatistiksel olarak anlamlı bir fark olup olmadığı araştııılmıştır.

Araştırmadan elde edilen veriler için SPSS for Windows 17.0 programıla analiz edilmiştir. Verilerin analizinde tanımlayıcı istatistiksel test olarak Kruska-Wallis $\mathrm{H}$, MannWhitney U testleri (sıklık, yüzde, ortalama, hipotez testleri) kullanılmıştır. Elde edilen sonuçlar \%95 güven aralığında ve $p<0.05$ anlamlılık düzeyinde değerlendirilmiştir.

\section{Bulgular}

Araştırmaya alınan hastaların \%45.6'sı $(n=26)$ tip 1, \%33.3'ü $(n=19)$ tip 2 DM saptanırken, \%21.1'inde $(n=12)$ yeni tanı $\mathrm{DM}$ tespit edilmiştir.

Tip 1 DM hastalarının ortalama yaşı $28.8 \pm 1.3$, tip 2 DM hastalarının $60.2 \pm 1.6$ ve yeni tanı DM hastalarının ise $39.5 \pm 1.8$ olarak bulunmuştur.

Araştırmaya alınan hastalar içerisinde 30 yaşın altında tip 2 DM görülmezken, 18-20 yaşlar arasında üç yeni tanı DM hastası tespit edilmiştir. Altmış yaş üzerinde hiç tip 1 ve yeni tanı DM hastası bulunmamıştır. Tip 1 DM hastası en çok 21-30 yaş arasında (\%34.6), tip 2 DM hastası en çok 51-60, 61-70 ve 71 yaş üzerinde (her üç grupta da \%26.3), yeni tanı DM hastası ise en çok 51-60 yaş arasında (\%33.3) tespit edilmiştir. Diyabet tipleri ile yaş grupları arasındaki fark istatistiksel olarak da anlamlı bulunmuştur $(p<0.05)$.

Tip 1 DM hastalarının \%73.1'i ( $n=19)$ kadın, \%26.9'u $(n=7)$ erkek, tip 2 DM hastalarının \%63.2'ü ( $n=12)$ kadın, \%36.8'i $(n=7)$ erkek, yeni tanı DM hastaların \%50.0' ı $(n=6)$ kadın, \%50.0'ı ( $n=6)$ erkektir.

Tip 1 DM hastalarının \%30.8'i $(n=8)$, tip 2 DM hastalarının \%21.1'i $(n=4)$, yeni tanı DM hastalarının ise \%16.7'sinde $(n=2)$ pH $<7.0$ olarak saptanmıştır.

Tip 1 DM hastalarının \%30.8'inde $(n=8)$, tip 2 DM hastalarının \%36.8'inde $(n=7)$, yeni tanı DM hastalarının ise $\% 25$ 'inde $(\mathrm{n}=3) \mathrm{HCO}^{3}$ düzeyi 0-5 aralığında bulunmuştur.

Plazma glukoz seviyesi tip 1 hastaların \%23.1'inde $(\mathrm{n}=6)$ 250-400 mg/dl, \%30.8'inde $(\mathrm{n}=8) 401-500 \mathrm{mg} /$ dl, \%23.1'inde $(n=6) 501-600 \mathrm{mg} / \mathrm{dl}, \% 7.7$ 'sinde $(n=2)$ $601-700 \mathrm{mg} / \mathrm{dl}$ ve yine $\% 7.7$ 'sinde $(\mathrm{n}=2) 701-800 \mathrm{mg} /$ dl aralığında bulunurken, \%7.7 hastada $(n=2) 800 \mathrm{mg} /$ dl'nin üstü değerler saptanmıştır. Tip 2 hastaların ise \%21.1'inde $(n=4) \quad 250-400 \mathrm{mg} / \mathrm{dl}, \% 10.5^{\prime}$ inde $(n=2)$ 401-500 mg/dl, \%31.6'sında $(\mathrm{n}=6)$ 501-600 mg/dl, 
\%15.8'inde $(n=3)$ 601-700 mg/dl, \%21.1'inde $(n=4)$ $701-800 \mathrm{mg} / \mathrm{dl}$ arası değerler bulunmuştur. Yeni tanı hastaların \%8.3'ünde ( $n=1)$ 250-400 mg/dl, \%25'inde $(\mathrm{n}=3)$ 401-500 mg/dl, \%25'inde $(\mathrm{n}=3) 501-600 \mathrm{mg} / \mathrm{dl}$, \%16.7'sinde $(n=2) 601-700 \mathrm{mg} / \mathrm{dl}, \% 8.3$ 'ünde $(n=1)$ 701-800 mg/dl, \%16.7'sinde ( $\mathrm{n}=2) 800 \mathrm{mg} / \mathrm{dl}$ üstü plazma glukoz seviyeleri saptanmıştır (Tablo 1).

Tip 1 DM hastaların \%7.6'sında $(n=5)$, tip 2 DM hastaların ise \%31.5'inde $(n=6)$ üst solunum yolu enfeksiyonu saptanmıştır. Yeni tanı DM hastaların da \%16.6'sında $(n=2)$ üst solunum yolu enfeksiyonu bulunmuştur.

Tip 1 DM hastaların \%11.5'inde ( $n=3)$, tip 2 DM hastaların \%21'inde $(n=4)$ ve yeni tanı DM hastaların yine \%33.3'ünde $(n=4)$ alt solunum yolu enfeksiyonu saptanmıştır.

Tip 1 DM hastaların \%15.3'ünde $(n=4)$, tip 2 DM hastaların \%26.3'ünde $(n=5)$, yeni tanı DM hastalarının ise $\% 25$ 'inde $(n=3)$ idrar yolu enfeksiyonu görülmüştür.

Tip 1 DM hastaların \%26.9'unda $(n=7)$, tip 2 DM hastaların \%15.7'sinde $(n=3)$ etiyolojide diyabete yönelik aldıkları diyet ve ilaç tedavisine uyumsuzluk saptanmışır.

Araştırmaya alınan hastaların kan glukoz, sodyum, potasyum değerleri ortalamalarının DM tipi değişkeni açısından anlamlı bir farklılık gösterip göstermediğini belirlemek amacıyla yapılan Kruskal-Wallis $\mathrm{H}$ testi sonuçlarına göre; grup ortalamaları arasındaki fark istatistiksel olarak anlamlı bulunmamıştır (sırasıyla; $K W=1.635 ; \quad p=0.442$; $K W=0.029 ; p=0.986 ; K W=3.097 ; p=0.213$.

Araştırmaya katılanların HbA1c ortalamalarının DM tipi değişkeni açısından anlamlı bir farklılık gösterip göstermediğini belirlemek amacıyla yapılan Kruskal-Wallis $\mathrm{H}$ testi sonuçlarına göre; grup ortalamaları arasındaki farkın istatistiksel olarak anlamlı olduğu tespit edilmiştir ( $K W=11.197 ; p=0.004)$.

Farklılığın hangi gruptan kaynaklandığını belirlemek üzere Mann-Whitney $U$ testi uygulanmıştır. Buna göre; yeni tanı DM hastalarının HbA1c değer puanı, tip 1 DM olanların HbA1c değer puanından (Mann-Whitney $\mathrm{U}=75.000 ; p=0.011$ ) ve tip $2 \mathrm{DM}$ olanların $\mathrm{HbA1C}$ değer puanından yüksektir (Mann-Whtney $U=36.000$; $p=0.002$ ).

\section{Tartışma}

DKA diyabetin en ölümcül akut komplikasyonlarından birisidir. Enfeksiyon ve tedavi uyumsuzluğu DKA'nın en sık rastlanan sebeplerini oluşturmaktadır. Bu vakalarının önemli bir bölümündeyse sebep belirlenememektedir (4). DKA en sık nedenleri Westphal ve ark.'nın (4) yaptığı çalışmada ve Yan ve ark.'nın yaptı̆̆ı çalışmada (5) en sık sebepler tip 1 DM hastalar için tedaviye uyumsuzluk olurken, tip 2 DM hastalar ve yeni tanı konulan DM hastaları grubunda enfeksiyon olarak bulunmuştur.

DKA açısından literatürle çalışmamızdaki sonuçlar benzerlik göstermektedir.

Araştırmamıza dahil edilen hastalardan tip 1 DM hasta grubunda en sık (DKA) sebebi (\%26.9) tedaviye uyumsuzluk bulunurken, tip 2 DM hastalarda en sık sebep (\%78.9) enfeksiyon olarak saptanmıştır.

Yeni tanı konulan DM hastaları grubundaysa en sık neden yine enfeksiyon (\%50) olarak bulunmuştur.

Westphal ve ark.'nın yaptığı çalışmada tip 1 DM hastaların \%23.6'sında, tip 2 DM hastaların ise \%24.1'inde etiyolojide geçerli bir neden saptanamazken, yeni tanı konulan hastalarda bu oran \%69.4 olarak bildirilmiştir (4). Yan ve ark.'nın yaptı̆̆ı çalışmadaysa tip 1 DM hastalarında \%15.6, tip 2 DM hastalarında \%24.7 ve yeni tanı konulan DM hastalarında bu oran \%40.6 olmuştur (5). Araştırmamızda tip 1 DM hastaların \%26.9'unda DKA etiyolojisinde geçerli bir neden bulunamazken, tip 2 DM hastalar için bu oran \%15.7, yeni tanı DM hastalarında ise \%41.6'dır.

DKA, kimi zaman diyabet tanısında ilk bulgu olabilmektedir. Bu hastaların tüm DKA hastalarına oranı \%7.1-\%27.5 arasında değiş̧mektedir. Araştırmamız da bu oran \%21 olarak bulunmuştur.

Balasubramanyam ve ark.'nın yaptığı çalışma da ortalama $\mathrm{pH}$ değerleri tip 1 diyabetli hastalarda 7.14 \pm 0.12 , tip 2 diyabetli hastalarda $7.17 \pm 0.12$, yeni tanı konulan diyabet hastalarındaysa $7.19 \pm 0.14$ olarak bulunmuştur (6). Yan ve ark.'nın yaptığı çalışma da ise ortalama pH değerleri tip 1 hastalarda $7.07 \pm 0.03$, tip 2 hastalar da $7.14 \pm 0.02$, yeni tanı diyabet hastalarındaysa 7.12 \pm 0.02 olarak bildirilmiştir (5). Wang ve ark.'nın yaptığı çalışma da ise ortalama pH değerleri tip 1 DM hastalar için $7.23 \pm 0.06$, tip 2 diyabet hastalarında $7.11 \pm 0.04$ olarak bulunmuştur (7). Araştırmamıza dahil olan hastaların başvuru sırasındaki arter kan gazında bakılan pH

\begin{tabular}{|c|c|c|c|}
\hline & \multicolumn{3}{|c|}{ Tipler } \\
\hline & TiP 1 & TiP 2 & Yeni Tanı \\
\hline Glikoz & $504.654 \pm 172.327$ & $547.000 \pm 148.753$ & $574.417 \pm 149.055$ \\
\hline Sodyum & $129.769 \pm 4.366$ & $129.579 \pm 5.092$ & $129.750 \pm 4.515$ \\
\hline Potasyum & $5.042 \pm 0.868$ & $4.815 \pm 0.999$ & $5.413 \pm 0.999$ \\
\hline HbA1c & $11.496 \pm 2.435$ & $10.763 \pm 2.830$ & $14.208 \pm 2.661$ \\
\hline
\end{tabular}


değerleri diğer çalışmalarla benzerlik göstermektedir. Bizim araştırmamızda da diğer çalışmalardaki gibi pH değerleri istatistiksel olarak anlamlı bulunmamıştır.

Yan ve ark.'nın yaptığı çalışma da ise ortalama $\mathrm{HCO}^{3}$ değerleri tip 1 diyabet hastalarında $6.4 \pm 0.8$, tip 2 diyabetlilerde $7.7 \pm 0.5$, yeni tanı diyabet hastalarındaysa $6.7 \pm 0.7$ olarak tespit edilmiştir (5). Nyenwe ve ark.'nın yaptığı çalışmada ise tip 1 hastalardan Afrika kökenli Amerikalılarda ortalama $\mathrm{HCO}^{3} 13.3 \pm 5.7$, Ispanyollarda ise $14.7 \pm 5.6$ bulunurken, bu oran tip 2 hastalarda sırasıyla

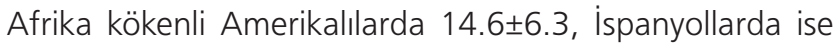
15.2 \pm 4.2 olarak bulunmuştur (7). Gerek bizim çalışmamız da gerekse diğer çalışmalarda başvuru esnasında hasta tipleri ve arter kan gazında bakılan $\mathrm{HCO}^{3}$ değerlerinin karşılaştırmaları istatistiksel olarak anlamlı değildir.

Nyenwe ve ark.'nın yaptığı çalışmada ise tip 1 hastalardan Afrika kökenli Amerikalılarda ortalama plazma glukoz değeri $641.4 \pm 267.8 \mathrm{mg} / \mathrm{dl}$ olurken, bu rakam ispanyollarda $631.4 \pm 192.3 \mathrm{mg} / \mathrm{dl}$ olarak bildirilmiş, aynı çalışmada tip 2 hastalarda Afrika kökenli Amerikalılarda ortalama plazma glukoz değeri $608.1 \pm 227.5 \mathrm{mg} / \mathrm{dl}$ olurken tip 2 diyabetlilerde $620.7 \pm 287.6 \mathrm{mg} / \mathrm{dl}$ olarak saptanmıştır (8). Yan ve ark.'nın yaptığı çalışma da ise ortalama plazma glukoz değerleri tip 1 hastalar için $504 \pm 31 \mathrm{mg} / \mathrm{dl}$, tip 2 hastalar için $638 \pm 24 \mathrm{mg} / \mathrm{dl}$ bulunurken, yeni tanı diyabetlilerde bu rakam $836 \pm 64 \mathrm{mg} / \mathrm{dl}$ olarak bildirilmiştir. Yan ve ark.'nın çalışmalarındaki bu değerler istatistiksel olarak anlamlı bulunmuştur (5). Balasubramanyam ve ark.'nın yaptığı çalışma da ise ortalama plazma glukozu tip 1 DM'lilerde $34.9 \pm 17.6 \mathrm{mmol} / \mathrm{l}$, tip 2 DM'lilerde $40.6 \pm 23.8$ $\mathrm{mmol} / \mathrm{l}$, yeni tanı DM'lilerdeyse $34.5 \pm 24.7 \mathrm{mmol} / \mathrm{l}$ olarak bulunmuştur. Balasubramanyam ve ark.'nın yaptığı çalışmadaki bu değerlerin bizim çalışmamızda da olduğu gibi istatistiksel olarak anlamlı olmadığı belirlenmiş̧tir (6). Wang ve ark.'nın yaptığı çalışma da ise ortalama plazma glukozu tip $1 \mathrm{DM}^{\prime}$ 'lilerde $36.2 \pm 3.7 \mathrm{mmol} / \mathrm{I}$, tip 2 DM'lilerde $38.5 \pm 3.3$ $\mathrm{mmol} / \mathrm{l}$ olarak bulunmuştur. Wang ve ark.'nın yaptığı çalışmadaki değerler de yine bizim çalışmamızda olduğu gibi istatistiksel olarak anlamlı değildi (7). Yine Nyenwe ve ark.'nın yaptığı çalışmada da plazma glukoz ortalamaları çalışmamızla benzer şekilde tipler açııından istatistiksel olarak anlamlı bulunmamıştır (8). Araştırmamızda hastaların plazma glukoz değerlerinin ortalaması tip 1 hastalarda $504.654 \pm 172.327 \mathrm{mg} / \mathrm{dl}$, tip 2 hastalarda $547.000 \pm 148.753$ $\mathrm{mg} / \mathrm{dl}$ ve yeni tanı konulanlarda $574.417 \pm 149.055 \mathrm{mg} / \mathrm{dl}$ olarak saptanmıştır. Yeni DM tanısı konulan hastalarımızın başvuru glukoz değerleri yüksek bulunmasına rağmen istatistiksel olarak anlamlı bulunmamıştır.

Nyenwe ve ark.'nın yaptığı çalışmada da yeni tanı DM hastalarında HbA1c değeri istatistiksel olarak anlamlı ölçülerde diğer diyabet gruplarından yüksek bulunmuştur (8).
Araştırmamıza dahil edilen hastaların HbA1c değerleri tüm gruplarda oldukça yüksektir. Ancak yeni tanı konulan DM hastalarında bu fark daha belirgindir. Yeni tanı konulan hastalardaki $\mathrm{HbA} 1 \mathrm{c}$ değerlerinin diğer grup hastalara oranla yüksekliği istatistiksel olarak da anlamlıdır. Acil servise başka nedenlerle başvuran hastalarda kan şekeri yüksekliğinin tespit edilmesi nadir görülen bir durum değildir. Bu tip hastalarda altta yatan DM tanısı açısından dikkatli olunması olası DKA ataklarının engellenmesi bakımından önemlidir.

Balasubramanyam ve ark.'nın yaptığı çalışma da ise tip 1 hasta grubunun ortalama serum sodyum değeri $134 \pm 6 \mathrm{mEq} / \mathrm{l}$, tip 2 hasta grubunun ortalama serum sodyum değeri $132 \pm 8 \mathrm{mEq} / \mathrm{l}$, yeni tanı konulan diyabet hastaları grubundaysa $132 \pm 4 \mathrm{mEq} / \mathrm{l}$ olarak bildirilmiştir (6). Nyenwe ve ark.'nın yaptığı çalışma da hastaların ortalama kan potasyum değerleri tip 1 DM hasta grubunda $5.3 \pm 0.9$ $\mathrm{mEq} / \mathrm{l}$, tip $2 \mathrm{DM}$ hastalarda $5.0 \pm 0.9 \mathrm{mEq} / \mathrm{l}$ bildirilmiştir (8). Balasubramanyam ve ark.'nın yaptığı çalışma da ise kan potasyum değerleri tip 1 DM hasta grubunda $5.2 \pm 1.2$ $\mathrm{mEq} / \mathrm{l}$, tip $2 \mathrm{DM}$ hasta grubunda $4.9 \pm 1.2 \mathrm{mEq} / \mathrm{l}$ olarak bildirilmiştir (6).

Gerek bizim çalışmamı da gerekse Balasubramanyam ve ark.'nın yaptığı çalışmada ortalama serum sodyum değerlerinin tipler açısından istatistiksel analizi anlamlı değildir. Ayrıca araştırmamızda da bahsi geçen diğer çalışmalarda da kan potasyum değerlerindeki farklılıklar istatistiksel olarak anlamlı bulunmamıştır.

\section{Sonuç}

Tip 1 DM hastalarda en sık neden tedaviye uyumsuzluk olarak saptanırken, tip 2 DM hastalarda ve yeni tanı konulan DM hastalarında enfeksiyon en sık görülen neden olarak saptanmıştır. Araştırmamızdaki hastaların \%21'i yeni tanı koyulan DM hastaları oluşmuştur. Bilinen diyabeti olmayan hastalarda saptanan bu yüksek oran acil servislerde hasta yaklaşımında DKA tanısının diyabeti olmayan hastalarda da mutlaka akılda tutulması gerektiğini göstermektedir. Acil servislerde hiperglisemi saptanan diyabetik olmayan hastalarda acil servis rutininde DM açısından daha ileri değerlendirmeler çoğu zaman yapılmamakta sözü geçen hiperglisemiler çoğu zaman metabolik ya da travmatik strese bağlanabilmektedir. Böylelikle gözden kaçan hastalar daha sonra DKA gibi diyabetin fatal komplikasyonlarıla acil servise geri gelebilmektedir.

Çalışmamızda emeği geçen herkese teşekkür ederiz.

Çalışmamızda herhangi maddi destek kullanılmamışır.

\section{Kaynaklar}

1. National diabetes fact sheet: general information and national estimates on diabetes in the United States, 2005. Atlanta, GA, U.S. Department of Health and Human Services, Centers for Disease Control and Prevention, 2005 
2. Goldman L., Ausiel D. Cecil medicine 23rd edition; 2007

3. Henderson WR, Chittock DR, Dhingra VK, et al. Hyperglycemia in acutely ill emergency patients-cause or effect? CJEM 2006;8:339-43.

4. Westphal SA. The occurrence of diabetic ketoacidosis in noninsulin-dependent diabetes andwly diagnosed diabetic adults. AmJ Med 1996;101:19-24.

5. Yan SH, Sheu WH, Song YM, et al. The occurrence of diabetic ketoacidosis in adults. Intern Med 2000;39:10-4.
6. Balasubramanyam A, Zern JW, Hyman DJ, et al. New profiles of diabetic ketoacidosis: type 1 vs type 2 diabetes and the effect of ethnicity. Arch Intern Med 1999;25;159:2317-22.

7. Wang ZH, Kihl-Selstam E, Eriksson JW. Ketoacidosis occurs in both Type 1 and Type 2 diabetes-a population-based study from Northern Sweden. Diabet Med 2008;25:867-70.

8. Nyenwe $E$, Loganathan $R$, Blum $S$, et al. Admissions for diabetic ketoacidosis in ethnic minority groups in a city hospital. Metabolism 2007;56:172-8. 